\title{
Van de redactie
}

\section{Keskin en het onderbouwen van verzoeken tot het horen van getuigen: een presumptie van verdedigingsbelang}

\author{
“Uitspraak EHRM: Hoge Raad zal jurisprudentie t.a.v. het horen van getuigen à charge moeten \\ aanpassen!"
}

\section{NTS $2021 / 2$}

Bovenstaand bericht is er slechts één uit de stroom aan berichten van gelijke strekking die op social media verscheen nadat het Europese Hof voor de Rechten van de Mens (hierna: EHRM) op 19 januari jl. arrest wees in de zaak Keskin. ${ }^{1}$ Met dat 'aanpassen' wordt gedoeld op de eisen die ons hoogste rechtscollege in een tweetal overzichtsarresten uit $2017^{2}$ - in het licht van de rechtspraak van het $\mathrm{EHRM}^{3}$ - stelt aan de motivering van verzoeken tot het oproepen en horen van getuigen. Zou die EHRM-rechtspraak door de Hoge Raad onjuist zijn geinterpreteerd? Dat zou vergaande consequenties kunnen hebben voor de praktijk, nu verzoeken om getuigen à charge ('prosecution mitnesses' in de terminologie van het $\mathrm{EHRM}^{4}$ ) ter zitting te horen - zelfs onder

1. EHRM 19 januari 2021, nr. 2205/16 (Keskin t. Nederland). De zaak is overigens nog niet onherroepelijk, nu Nederland op grond van art. 43 en 44 van het EVRM gedurende 3 maanden de mogelijkheid heeft te vragen om een verwijzing naar de Grand Chamber van het Hof. Het is echter onwaarschijnlijk dat dit zal gebeuren, nu de Nederlandse Regering op 29 december 2016 door middel van een zogenaamde “Unilateral Declaration" reeds heeft erkend dat art. 6 EVRM is geschonden.

2. HR 4 juli 2017, ECLI:NL:HR:2017:1015, NJ 2017/440 en ECLI:NL:HR 2017:1219, NJ 2017/441 beide m.nt. Kooijmans.

3. Meer bepaald de 'pre Al-Khawaja and Tahery -arresten' Perna t. Italië (EHRM 6 mei 2003, nr. 48898/99) en Poropat t. Slovenië (EHRM 9 mei 2017, nr. 21668/12).

4. Getuigen ten aanzien van wie het openbaar ministerie oordeelt dat deze "a relevant source of information" zijn en "relies on his or her testimony at the trial". het 'verdedigingsbelang'5 - op grote schaal worden afgewezen op de grond dat de rechter weliswaar terughoudend moet zijn bij de afwijzing van een verzoek om een getuige te horen, doch dat het verzoek door de verdediging wel naar behoren moet worden gemotiveerd. Volgens de Hoge Raad mag van de verdediging worden verlangd dat zij ten aanzien van iedere van de door haar opgegeven getuigen motiveert waarom het horen van deze getuige van belang is voor enige in de strafzaak uit hoofde van de artikelen 348 en $350 \mathrm{~Sv}$ te nemen beslissing. Er zullen dus redenen moeten worden gegeven voor het (nogmaals en ditmaal ter zitting) doen horen van getuigen à charge die reeds in het vooronderzoek zijn gehoord. Dit wordt in de praktijk veelal zo uitgelegd dat niet volstaat dat een advocaat aangeeft bepaalde getuigen te willen horen omdat deze belastend hebben verklaard bij de politie en dat hij deze daarom aan de tand wil voelen. ${ }^{6}$ De advocaat zal moeten aangeven over welke onderwerpen hij de getuige wil bevragen en op

5. “...alleen dan kan worden gezegd dat de verdachte door afwijzing van het verzoek redelijkerwijs niet in zijn verdediging wordt geschaad, indien de punten waarover de getuige kan verklaren, in redelijkheid niet van belang kunnen zijn voor enige in zijn strafzaak te nemen beslissing dan wel redelijkerwijze moet worden uitgesloten dat die getuige iets over bedoelde punten zou kunnen verklaren." (r.o. 2.5 uit HR 4 juli 2017, ECLI:NL:HR:2017:1219, NJ 2017/441.)

6. Zie ook de reden voor het Hof Arnhem-Leeuwarden in de Keskin-zaak om het verzoek tot het horen van de betreffende getuigen a charge af te wijzen: "In that context the Court of Appeal noted that the defence had not indicated on what points the statements of witnesses $A$ to $G$ were incorrect" (r.o. 55). 
welke onderdelen de getuige onjuist zou hebben verklaard, dan wel nader zou moeten verklaren. Een andere veelgehoorde (bijkomende of - zo men wil - versterkende) reden in de Nederlandse rechtszalen voor het afwijzen van getuigen à charge is het feit dat de verdachte zich op zijn zwijgrecht beroept. Wel getuigen willen horen, maar zelf niets zeggen? Waarom de geloofwaardigheid of betrouwbaarheid van een ander willen betwisten als jij zelf de kaken stijf op elkaar houdt?! ${ }^{7}$

Het Keskin-arrest lijkt duidelijk te maken dat de uitleg door Hoge Raad van de EHRM-rechtspraak (en de daarop gebaseerde uitleg van menig feitenrechter) te streng en zelfs onjuist is. Het EHRM citeert de jurisprudentie van ons hoogste rechtscollege uitvoerig en geeft aan dat die deels gedateerd is (in die zin dat de door de Hoge Raad aangehaalde jurisprudentie dateert van voor de koerswijziging van het EHRM) en legt vervolgens uit dat de Hoge Raad daarin - voor zover het betreft 'prosecution mitnessses' - ten onrechte uit arresten als Perna ${ }^{8}$ en Poropat ${ }^{9}$ afleidt dat de verdediging het horen ervan 'naar behoren moet motiveren' in de situatie dat "the prosecution decides that a particular person is a relevant source of information and relies on his or her testimony at the trial, and if the testimony of that mitness is used by the court to support a guilty verdict". Alsdan "it must be presumed that his or her personal appearance and questioning are necessary". ${ }^{10}$ Het ontbreken van nadere motivering van het verzoek kan dan niet gelden als " $a$ good reason for the non-attendance of mitnesses at the trial":

"56. As to any requirement for the defence to substantiate a request to examine prosecution mitnesses, the Court reiterates [...] that the underlying principle of the right contained in Article $6 \oint 3$ (d) of the Convention in relation to the examination of prosecution mitnesses is that the defendant in a criminal trial should have an effective opportunity to challenge the evidence against him or her. This principle requires that a defendant be able to test the truthfulness and reliability of evidence provided by mitnesses which incriminates him or her, by having them orally examined in his or her presence, either at the time

7. Die argumentatie is ook terug te zien in de motivering van het Hof Arnhem-Leeuwarden: “....and, in addition, that the applicant had availed himself of his right to remain silent when he had been interviewed by police, and that he had not wished to reply to specific questions about his activities for company Fr. which had been put to him by the Court of Appeal at the hearing" (r.o. 55). Dit is voor het EHRM geen valide reden: "To the extent that these additional observations of the Court of Appeal ought to be interpreted as meaning that it found those facts relevant for its refusal to secure the attendance of the witnesses, the Court considers that the right of an accused to cross-examine witnesses against him or her cannot be made dependent on his or her renunciation of the right to remain silent."

8. EHRM 6 mei 2003, nr. 48898/99 (Perna t. Italië).

9. EHRM 9 mei 2017, nr. 21668/12 (Poropat t. Slovenië).

10. Die conclusie had A-G Spronken, nota bene in haar conclusie voorafgaand aan een van die door het EHRM aangehaalde arresten van de Hoge Raad (zie CAG Spronken (punt 3.8.37-38) voor HR 4 juli 2017, ECLI:NL:HR:2017:1015, NJ 2017/440), ook al getrokken. Ook Kooijmans laat zich in diens noot onder voornoemd arrest gereserveerd uit over het gemak waarmee de Hoge Raad de eis van (enige) onderbouwing veralgemeniseert naar alle getuigenverzoeken, dus zowel à charge als décharge. the mitness mas making the statement or at some later stage of the proceedings ]...J. Therefore, in a situation where the prosecution relies on such a mitness statement and the trial court may use that statement to support a guilty verdict, the interest of the defence in being able to have the pitness concerned examined in his or her presence must be presumedand,as such, constitutes all the reason required to accede to a request by the defence to summon that witness [...]."

Dit duidt er dus op dat het feit dat dergelijke belastende verklaringen (van getuigen die nog niet eerder door de verdediging zijn (kunnen worden) bevraagd en die de rechter voor het bewijs zou kunnen bezigen ${ }^{11}$ ) zich in het dossier bevinden, reeds voldoende reden is ${ }^{12}$ voor de verdediging om de getuige te willen bevragen. Afwijzing is dan wel mogelijk, maar de rechter zal daartoe het 'stappenplan' uit Al-Khawaja en Tahery ${ }^{13}$ (dat in Schatschaschwili $^{14}$ meer de trekken heeft gekregen van een overall beoordeling) moeten doorlopen, ${ }^{15}$ waarbij dus geldt dat een gebrek aan onderbouwing of het feit dat de verdachte zelf zwijgt niet "a good reason" oplevert. Wanneer de bewuste verklaring(en) niet "the sole or decisive basis" voor een veroordeling lijkt te (hoeven) zijn, kan het verzoek strikt genomen alsnog worden afgewezen, maar dat is voor de zittingsrechter (onder omstandigheden) buitengewoon gevaarlijk, omdat deze daarmee in feite - in een heel vroeg stadium van het strafproces - al duidelijk lijkt te maken reeds een volledig (of afdoende) beeld van de zaak te hebben verkregen en daarmee ook zijn oordeel al klaar te hebben. Het risico - terecht - van (de schijn van) vooringenomenheid te worden beticht, ligt dan op de loer. Met name over de afwijzing van verzoeken op deze grond zal de komende tijd ongetwijfeld nog uitvoerig gaan worden gediscussieerd. Dit neemt echter niet weg dat het afwijzen van (tijdig) gedane verzoeken tot het horen van belastende getuigen niet meer kan worden gedaan op grond van een soort van 'pre-criterium' dat door de verdediging onvoldoende is duidelijk gemaakt wat er schort aan de door de bewuste getuigen afgelegde verklaringen. Duiding van EHRMrechtspraak is vanwege de casuistiek altijd lastig, maar hier lijkt Straatsburg toch heldere wijn te schenken. Anders dan de Hoge Raad stelt, is het niet aan de verdediging om een verzoek tot het horen van een getuige à charge (substantieel) te onderbouwen. Het belang van de verdediging om die getuige te horen wordt aanwezig

11. Het woord "may" is hier van belang, nu de rechter uiteraard niet te snel en in een (relatief) vroeg stadium kan oordelen dat een betreffende verklaring niet voor het bewijs zal worden gebruikt wegens het risico van vooringenomenheid.

12. In de zin van "a good reason"

13. EHRM 15 december 2011, nr. 26766/05 (Al-Khawaja and Tahery t. Verenigd Koninkrijk).

14. EHRM 15 december 2015, nr. 9154/10 (Schatschaschwili t. Duitsland).

15. (1) Is er een goede reden voor afwezigheid van de getuige(n); (2) is de verklaring 'sole or decisive' voor de bewezenverklaring, en (3) zijn er voldoende 'counterbalancing factors', waaronder procedurele waarborgen, om de beperkingen die de verdediging ondervindt te compenseren en het recht van de verdachte op een eerlijk proces te waarborgen? 
verondersteld totdat het tegendeel blijkt. Het is daarom aan de zittingsrechter die voornemens is om het verzoek af te wijzen om de gronden daarvoor overtuigend en indachtig de beoordelingsfactoren uit Al-Khawaja en Tahery en Schatschaschwili uiteen te zetten. Dat kan betekenen dat het in de praktijk (iets) lastiger wordt om dergelijke verzoeken af te wijzen en dat de zittingsrechter iets scheutiger moet zijn met het toekennen van verzoeken en er dus meer - en geheel in lijn met het uitgangspunt van het onmiddellijkheidsbeginsel dat door het EHRM al sinds jaar en dag wordt verkon$\operatorname{digd}(!)$ - getuigen ter zitting (of bij de rechter-commissaris) moeten worden gehoord. De vraag is of dat echt bezwaarlijk is. Past het niet dat de zittingsrechter zich persoonlijk een oordeel vormt over de betrouwbaarheid van die (doorslaggevende) getuigen(verklaringen) die hij voor de bewezenverklaring wil bezigen? ${ }^{16}$ Anderzijds moet een en ander in de praktijk wel werkbaar blijven. In zaken waarin er veel (ander) sterk bewijs is biedt ook 'Keskin' nog altijd de mogelijkheid om een verzoek tot het horen van 'prosecution witnesses' af te wijzen. Voorzichtigheid is echter geboden: met name de stappen 2 ("whether the evidence of the absent mitnesses mas the sole or decisive basis for the applicant's conviction") en 3 ("Whether there mere sufficient counterbalancing factors") uit Al-Khawaja en Tahery en Schatschaschwili zullen zorgvuldig moeten worden genomen teneinde de 'overall fairness' te garanderen.

16. Zie in dit kader ook L. van Lent, A. Smolders en M. Malsch, "' We kennen allemaal de stukken..." Pleidooi voor een debat over een onmiddellijker strafproces in Nederland', DD 2020/38 die onzes inziens terechte kritiek uiten op een aantal veronderstelde 'voordelen' van de huidige Nederlandse benadering en op goede gronden pleiten voor een meer ruimhartige toepassing van het onmiddellijkheidsbeginsel in het Nederlandse strafproces. 